\title{
Medical and Dietary Uses of N-Acetylcysteine
}

\author{
Špela Šalamon ${ }^{1}{ }^{1}$, Barbara Kramar $^{2}$, Tinkara Pirc Marolt ${ }^{2}$, Borut Poljšak $^{3}$ and \\ Irina Milisav $2,3, *$ (D) \\ 1 Center for human molecular genetics and pharmacogenomics, Faculty of Medicine, University of Maribor, \\ SI-2000 Maribor, Slovenia; spela.salamon@gmail.com \\ 2 Institute of Pathophysiology, Faculty of Medicine, University of Ljubljana, Zaloška 4, SI-1000 Ljubljana, \\ Slovenia; barbara.kramar@mf.uni-lj.si (B.K.); tinkara.pircmarolt@mf.uni-lj.si (T.P.M.) \\ 3 University of Ljubljana, Faculty of Health Sciences, Laboratory of Oxidative Stress Research, Zdravstvena \\ pot 5, SI-1000 Ljubljana, Slovenia; borut.poljsak@zf.uni-lj.si \\ * Correspondence: irina.milisav@mf.uni-lj.si
}

Received: 8 March 2019; Accepted: 23 April 2019; Published: 28 April 2019

check for updates

\begin{abstract}
N-acetylcysteine (NAC), a plant antioxidant naturally found in onion, is a precursor to glutathione. It has been used as a drug since the 1960s and is listed on the World Health Organization (WHO) Model List of Essential Medicines as an antidote in poisonings. There are numerous other uses or proposed uses in medicine that are still in preclinical and clinical investigations. NAC is also used in food supplements and cosmetics. Despite its abundant use, there are projections that the NAC global market will grow in the next five years; therefore, the purpose of this work is to provide a balanced view of further uses of NAC as a dietary supplement. Although NAC is considered a safe substance, the results among clinical trials are sometimes controversial or incomplete, like for many other antioxidants. More clinical trials are underway that will improve our understanding of NAC applicability.
\end{abstract}

Keywords: N-acetylcysteine; acetylcysteine; pharmacology; physiology; dietary supplements; aging; sports

\section{Introduction}

$\mathrm{N}$-acetylcysteine (also known as $\mathrm{N}$-acetyl-cysteine, NAC) is a precursor to the amino acid L-cysteine and consequently the antioxidant glutathione (GSH) [1]. It is most notably found in plants of the Allium species, especially in the onion (Allium cepa, $45 \mathrm{mg} \mathrm{NAC} / \mathrm{kg}$ ) [2,3]. The sulfhydryl group (-SH) within the NAC molecule directly scavenges reactive oxygen species (ROS) [4], modulates the redox state of the N-methyl-D-aspartate (NMDA) and $\alpha$-amino-3-hydroxy-5-methyl-4-isoxazolepropionic acid (AMPA) receptors (neurotransmitter effect) [5], and inhibits the nuclear factor kappa-light-chain-enhancer of activated B cells (NF- $\mathrm{B}$ ) to modulate cytokine synthesis (anti/pro-inflammatory effect) [6]. Unlike GSH itself, NAC has better oral and topical bioavailability [7,8]. Even though it has been used for more than 50 years, there are still many controversies surrounding it as a medicine as well as a dietary supplement. Several review articles have focused on various medical uses of NAC, some more general [9] and others highly specific dealing with NAC use only in a particular condition such as hyperglycaemia-induced oxidative damage [10], liver diseases [11], and traumatic brain injury [12]. Other reviews have discussed the use of NAC as a dietary supplement in psychiatric conditions by itself [13] or in conjunction with other supplements [14,15]. However, we were unable to find a review of both medical and supplementary uses of NAC. 


\section{Molecular Mechanisms: Both Sides of the Redox Equation}

GSH is the most abundant intracellular free thiol, and its decrease (and the increase in its redox couple oxidized glutathione, GSSG) has a crucial role in cell oxidative capacity [16]. It is required for stem cell function [17], and its depletion triggers cell death pathways [18]. Cellular oxidative stress is often seen as a GSH deficiency that is characteristic of many pathological conditions such as heart disease [19], diabetes [20], neurodegenerative disease [21], AIDS [22], as well as normal aging [23]. Though primarily seen as an antioxidant, NAC also has pro-oxidative effects. While NAC can scavenge several ROS (including $\left.\mathrm{HOCl}, \mathrm{ONOO}^{-}, \mathrm{RO}_{2}^{\bullet}\right)$ [24] and hydroxyl radicals $\left(\mathrm{OH}^{\bullet}\right)$ [25], it has a poor ability for sequestering $\mathrm{O}_{2}^{\bullet-}$ [26] and hydrogen peroxide $\left(\mathrm{H}_{2} \mathrm{O}_{2}\right)$ in vitro [27]. NAC can behave as an oxidant by undergoing auto-oxidation in high concentrations or in the presence of transition metals. NAC can reduce transitional metals and promote the formation of ROS via Fenton-like chemistry or the production of thiyl radical:

$$
\mathrm{NAC}(\mathrm{SH})+\mathrm{Fe}^{3+} \rightarrow \mathrm{NAC}\left(\mathrm{S}^{\bullet-}\right)+\mathrm{Fe}^{2+}+\mathrm{H}^{+}
$$

For example, by reducing ferric iron to its catalytic, active $\mathrm{Fe}^{2+}$ form, NAC enhances the production of hydroxyl radicals in the in vitro system with $\mathrm{Fe}(\mathrm{III})$-citrate and $\mathrm{H}_{2} \mathrm{O}_{2}$ [28]. Dose-dependent oxidative damage to DNA was observed in the presence of NAC in the presence of the transition metal, copper [29]. Besides, the products of pro-oxidant reactions mediated by NAC are involved in altering the redox-sensitive NF- $\mathrm{KB}$ signal transduction pathway activation; mitogen activated protein kinase p38 (p38MAPK) and c-Jun N-terminal kinase (JNK) phosphorylation [30,31]. The antioxidant and pro-oxidant effects of NAC have been discussed in greater detail elsewhere [32].

\section{Medical Use of NAC}

NAC has been an established drug since the 1960s; it is on the World Health Organization's List of 40 Essential Medicines [33] and is available as an inexpensive generic drug. It has been classically used in paracetamol overdose [34] and as a mucolytic [35], as well as to combat the toxicity of various substances that can cause generation of free radicals, such as carbon monoxide and x-ray contrasts [36]. The NAC products currently approved by Food and Drug Administration (FDA) are listed in Table 1. NAC is also used in the complementary treatment of neurological and neuropsychiatric disorders [5,35]. One death due to an anaphylactic reaction was described following an intravenous (IV) injection of $150 \mathrm{mg} / \mathrm{kg}$ of NAC in a 40 year old asthmatic woman in 2002. At comparable IV doses, vomiting was also reported in $11 \%$ of patients [37]. However, oral NAC seems to be associated with very few side effects and is considered to have an excellent safety profile [35]. One case of angioedema after oral NAC administration was described in 1997 [38]. Clinical studies have revealed benefits of NAC also in non-alcoholic steatohepatitis [39], arterial hypertension of diabetic etiology [40], chronic obstructive pulmonary disease (COPD) [41,42] and chronic bronchitis [43], substance abuse disorders [44], recurrent unexplained pregnancy loss [45], male infertility [46], polycystic ovary syndrome [47], diabetic retinopathy, age-related macular degeneration, and cataract and dry eye syndrome [4]. In total, 300 clinical studies (291 clinical trials) of NAC are listed in ClinicalTrials.gov [48] in April 2019 (Table 2). The most common disorders that were investigated by listed interventional trials with NAC (without the currently active studies) included renal disorders (48 trials) with an emphasis on radiocontrast nephropathy prevention, chronic kidney disease, and renoprotection during surgery; and neurological and psychiatric disorders (36 trials), leading with Parkinson's disease, schizophrenia, bipolar, autistic, and behavioral disorders. Schizophrenia, for instance, has been linked to mitochondrial abnormalities, glutathione deficiency, and increased oxidative stress in the brain. Negative and general symptoms in schizophrenia may be reduced after 8-24 weeks of adjunctive treatment with NAC [49] in neuropsychiatric disorders and are discussed in greater detail in a recent review [50]. Addictive disorders (23 trials) are also a common target, with alcohol, tobacco, cocaine, cannabis, and other types of dependence. The NMDA receptors that NAC modulates may be involved 
in addiction [51], and at least three reviews discuss the use of NAC in addictive disorders $[44,52,53]$ and emphasize the reduction of cravings for the substance in question. Among other commonly investigated uses of NAC were applications in gastrointestinal and pulmonary diseases. The majority of the 54 currently active interventional studies are investigating the role of NAC in addictive disorders, mental health, and neurodegenerative diseases, followed by cancer/cancer treatment side-effects, cardiovascular diseases, and surgery complications/trauma.

The suspended, terminated, or withdrawn studies listed in ClinicalTrals.gov are in Table 3. Termination reasons, such as no improvement and opposite results, are recorded in only 3 out of the 23 trials. Insufficient funds and insufficient recruitment are the major termination/ suspension/ withdrawal reason [48]. There are a few reports of the NAC study premature termination in the literature. High doses of NAC did not improve respiratory health in patients with COPD and chronic bronchitis; the study was prematurely terminated [54]. The decision was based on a potential safety issue, as it was reported that NAC and vitamin E, given orally, induced lung cancer in mice. This finding was reproduced in cell lines from human and mice lung tumors [55]. Additionally, there was no indication of improvement of COPD/chronic bronchitis in the 23 patients that received $1800 \mathrm{mg}$ NAC twice daily for 8 weeks compared to the equal number of subjects receiving placebo [54]. Results of a 24-week oral NAC supplementation of cystic fibrosis patients revealed that NAC recipients maintained their lung function without a significant effect on the biomarkers of neutrophilic inflammation [56]. Another trial was prematurely terminated in 2018 due to the absence of between-group differences in the rates of contrast-associated acute kidney injury; there was no noticeable benefit of the oral NAC on the contrast-associated acute kidney injury prevention, no noticeable improvement on the need for dialysis, persistent kidney injury or death in subjects at high risk of renal complications because of angiography [57]. Similar conclusions were reached from the "Acetylcysteine for contrast-induced neuropathy" trial [58]. 
Table 1. Overview of Food and Drug Administration FDA-approved N-acetyl-cysteine (NAC) drugs and their indications.

\begin{tabular}{|c|c|c|c|c|c|}
\hline Route & Administration & Strength & No.* & $\begin{array}{l}\text { Medical Condition/ } \\
\text { Therapy Type }\end{array}$ & Indication \\
\hline Effervescent tablet & Intravenous & $\begin{array}{c}200 \mathrm{mg} / \mathrm{mL} \\
(6 \mathrm{~g} / 30 \mathrm{~mL}) \\
\\
500 \mathrm{mg} \\
2.5 \mathrm{~g}\end{array}$ & 7 & $\begin{array}{l}\text { Poisoning/ } \\
\text { antidote }\end{array}$ & $\begin{array}{l}\text { Acetaminophen overdose reduction; } \\
\text { Prevention of acute hepatic injury; } \\
\text { Hepatic injury from repeated supratherapeutic ingestion. }\end{array}$ \\
\hline Solution & Oral & $\begin{array}{l}10 \% \\
20 \%\end{array}$ & 3 & & $\begin{array}{l}\text { Abnormal, viscid, inspissated mucous secretions in } \\
\text { chronic }^{* *} \text { and acute } \\
\text { Pulmonary complications of cystic fibrosis; }\end{array}$ \\
\hline Solution & Inhalation & $\begin{array}{l}10 \% \\
20 \%\end{array}$ & 3 & $\begin{array}{l}\text { Bronchopulmonary } \\
\text { disorders/ } \\
\text { Adjuvant therapy }\end{array}$ & $\begin{array}{c}\text { Tracheostomy care; } \\
\text { Pulmonary complications associated with surgery; } \\
\text { Use during anesthesia; } \\
\text { Post-traumatic chest conditions; } \\
\text { Atelectasis due to mucous obstruction and diagnostic } \\
\text { bronchial studies } \\
\text { b***. }\end{array}$ \\
\hline
\end{tabular}

*: Number of drugs, currently on the market. **: Chronic bronchopulmonary disease: chronic emphysema, emphysema with bronchitis, chronic asthmatic bronchitis, tuberculosis, bronchiectasis, and primary amyloidosis of the lung. ***: Acute bronchopulmonary disease: pneumonia, bronchitis, and tracheobronchitis. ${ }^{* * * *}$ : Diagnostic bronchial studies: bronchograms, bronchospirometry, and bronchial wedge catheterization. 
Table 2. NAC clinical trials registered at ClinicalTrials.gov [48]. The number of studies is displayed according to the study status, tested medical conditions of currently active studies, tested medical conditions in completed studies, study phase and tested medical conditions of currently active studies, study phase, and tested medical conditions of completed studies.

\begin{tabular}{|c|c|}
\hline Status & Count \\
\hline Completed & 159 \\
\hline Not yet recruiting & 14 \\
\hline Active & 54 \\
\hline Withdrawn/terminated/suspended & 24 \\
\hline Unknown status & 40 \\
\hline Grand Total & 291 \\
\hline Medical Conditions (Active Studies) & Count \\
\hline Addiction & 12 \\
\hline Cancer/chemotherapy side effects & 5 \\
\hline Cardiovascular diseases & 5 \\
\hline Gastrointestinal diseases & 4 \\
\hline Genetic disorders & 1 \\
\hline Graft/stem cell complications/trauma & 4 \\
\hline Infectious diseases & 1 \\
\hline Metabolic diseases & 1 \\
\hline Neuro/psychiatric disorders & 12 \\
\hline Obstetrics & 2 \\
\hline Poisoning antidote & 1 \\
\hline Pulmonary diseases & 1 \\
\hline Surgery complications/trauma & 5 \\
\hline Grand Total & 54 \\
\hline Medical Conditions (Completed Studies) & Count \\
\hline Addiction & 17 \\
\hline Blood disorders & 4 \\
\hline Cancer/chemotherapy side effects & 2 \\
\hline Cardiovascular diseases & 10 \\
\hline Dermatologic disorders & 2 \\
\hline Gastrointestinal diseases & 15 \\
\hline Genetic disorders & 1 \\
\hline Infectious diseases & 3 \\
\hline Metabolic diseases & 8 \\
\hline Muscle disorders & 1 \\
\hline Neuro/psychiatric disorders & 24 \\
\hline Obstetrics & 11 \\
\hline Ophthalmological diseases & 5 \\
\hline ORL & 5 \\
\hline Other & 4 \\
\hline Poisoning antidote & 2 \\
\hline Pulmonary diseases & 13 \\
\hline Renal disorders & 31 \\
\hline Surgery complications/trauma & 1 \\
\hline Grand Total & 159 \\
\hline Phase/Medical Conditions (Active Studies) & Count \\
\hline Early Phase 1 & 5 \\
\hline Addiction & 2 \\
\hline Metabolic diseases & 1 \\
\hline Neuro/psychiatric disorders & 1 \\
\hline Pulmonary diseases & 1 \\
\hline Not Applicable & 10 \\
\hline Cardiovascular diseases & 2 \\
\hline Gastrointestinal diseases & 1 \\
\hline Graft/stem cell complications/trauma & 1 \\
\hline Neuro/psychiatric disorders & 4 \\
\hline Obstetrics & 1 \\
\hline Surgery complications/trauma & 1 \\
\hline Phase 1 & 4 \\
\hline Addiction & 1 \\
\hline Cancer/chemotherapy side effects & 1 \\
\hline Neuro/psychiatric disorders & 1 \\
\hline Poisoning antidote & 1 \\
\hline
\end{tabular}


Table 2. Cont.

\begin{tabular}{|c|c|}
\hline Phase $1 \mid$ Phase 2 & 3 \\
\hline Cancer/chemotherapy side effects & 2 \\
\hline Gastrointestinal diseases & 1 \\
\hline Phase 2 & 13 \\
\hline Addiction & 6 \\
\hline Cancer/chemotherapy side effects & 1 \\
\hline Gastrointestinal diseases & 1 \\
\hline Genetic disorders & 1 \\
\hline Graft/stem cell complications/trauma & 1 \\
\hline Infectious diseases & 1 \\
\hline Neuro/psychiatric disorders & 2 \\
\hline Phase $2 \mid$ Phase 3 & 3 \\
\hline Addiction & 1 \\
\hline Graft/stem cell complications/trauma & 1 \\
\hline Obstetrics & 1 \\
\hline Phase 3 & 8 \\
\hline Cancer/chemotherapy side effects & 1 \\
\hline Cardiovascular diseases & 3 \\
\hline Neuro/psychiatric disorders & 2 \\
\hline Surgery complications/trauma & 2 \\
\hline Phase 4 & 8 \\
\hline Addiction & 2 \\
\hline Gastrointestinal diseases & 1 \\
\hline Graft/stem cell complications/trauma & 1 \\
\hline Neuro/psychiatric disorders & 2 \\
\hline Surgery complications/trauma & 2 \\
\hline Grand Total & 54 \\
\hline Phase/Medical Conditions (Completed Studies) & Count \\
\hline Early Phase 1 & 3 \\
\hline Addiction & 1 \\
\hline Blood disorders & 1 \\
\hline ORL & 1 \\
\hline Not Applicable & 18 \\
\hline Cardiovascular diseases & 1 \\
\hline Gastrointestinal diseases & 3 \\
\hline Metabolic diseases & 3 \\
\hline Neuro/psychiatric disorders & 2 \\
\hline Obstetrics & 2 \\
\hline Pulmonary diseases & 2 \\
\hline Renal disorders & 5 \\
\hline Phase 1 & 22 \\
\hline Addiction & 3 \\
\hline Cancer/chemotherapy side effects & 1 \\
\hline Cardiovascular diseases & 1 \\
\hline Gastrointestinal diseases & 2 \\
\hline Neuro/psychiatric disorders & 4 \\
\hline Ophthalmological diseases & 4 \\
\hline ORL & 1 \\
\hline Other & 4 \\
\hline Pulmonary diseases & 1 \\
\hline Renal disorders & 1 \\
\hline Phase 1|Phase 2 & 12 \\
\hline Addiction & 2 \\
\hline Blood disorders & 1 \\
\hline Infectious diseases & 1 \\
\hline Metabolic diseases & 3 \\
\hline Neuro/psychiatric disorders & 2 \\
\hline Obstetrics & 2 \\
\hline Renal disorders & 1 \\
\hline
\end{tabular}


Table 2. Cont.

\begin{tabular}{|c|c|}
\hline Phase 2 & 47 \\
\hline Addiction & 8 \\
\hline Blood disorders & 1 \\
\hline Cancer/chemotherapy side effects & 1 \\
\hline Cardiovascular diseases & 4 \\
\hline Dermatologic disorders & 1 \\
\hline Gastrointestinal diseases & 2 \\
\hline Genetic disorders & 1 \\
\hline Infectious diseases & 1 \\
\hline Metabolic diseases & 1 \\
\hline Muscle disorders & 1 \\
\hline Neuro/psychiatric disorders & 14 \\
\hline Obstetrics & 1 \\
\hline Ophthalmological diseases & 1 \\
\hline ORL & 1 \\
\hline Pulmonary diseases & 2 \\
\hline Renal disorders & 7 \\
\hline Phase 2|Phase 3 & 8 \\
\hline Gastrointestinal diseases & 1 \\
\hline Obstetrics & 1 \\
\hline ORL & 1 \\
\hline Renal disorders & 5 \\
\hline Phase 3 & 20 \\
\hline Addiction & 2 \\
\hline Blood disorders & 1 \\
\hline Cardiovascular diseases & 2 \\
\hline Dermatologic disorders & 1 \\
\hline Gastrointestinal diseases & 4 \\
\hline Infectious diseases & 1 \\
\hline Obstetrics & 2 \\
\hline Pulmonary diseases & 2 \\
\hline Renal disorders & 5 \\
\hline Phase 4 & 29 \\
\hline Addiction & 1 \\
\hline Cardiovascular diseases & 2 \\
\hline Gastrointestinal diseases & 3 \\
\hline Metabolic diseases & 1 \\
\hline Neuro/psychiatric disorders & 2 \\
\hline Obstetrics & 3 \\
\hline ORL & 1 \\
\hline Poisoning antidote & 2 \\
\hline Pulmonary diseases & 6 \\
\hline Renal disorders & 7 \\
\hline Surgery complications/trauma & 1 \\
\hline Grand Total & 159 \\
\hline
\end{tabular}

Pre-clinical studies imply that NAC could have more uses in supportive care and preventing human disease. Examples include Alzheimer's disease [59,60], asthma [61], inflammatory bowel disease [62], influenza [63], intrauterine growth retardation [64], obesity and insulin resistance [65-68], ischemic cardiovascular disease [69,70], heavy metal toxicity [71,72], diabetic neuropathy [73], and age-related memory impairment [74]. Due to its capacity to break down biofilms and improve antibiotic permeability, it is promising as an adjuvant antimicrobial drug [75]. Several pre-clinical studies have also demonstrated that NAC supplementation leads to life extension and diminished effects of aging, in invertebrates [76-79] as well as mammals [80] and in human breast epithelial stem cells [81]. Such findings have yet to be replicated in humans. This is likely not solely due to NAC's radical scavenging activity but also at least in part to telomerase activation and apoptosis inhibition [82], as is evidenced also by its capacity to delay oocyte aging [83]. However, antioxidants have the potential to either lengthen or shorten lifespan, depending on the dose and redox balance [84].

The role of NAC in the prevention and treatment of cancer is controversial, and it is discussed in more detail below. NAC has also attracted considerable attention as a sports supplement that can 
reduce muscle fatigue, improve athletic performance, and aid muscle recovery [85]. Although NAC is a well-known antioxidant and an old generic drug with several established clinical applications, more potential uses are still inadequately investigated. One of the main challenges of NAC as a medicine and a supplement is its broad range of effects and applications, far too few of which are well studied, in spite of a large effort in conducting preclinical and clinical trials.

Table 3. Medical conditions investigated by withdrawn, terminated, and suspended studies listed by ClinicalTrials.gov [48]. Listed: number of trials listed at ClinicalTrials.gov [48]; Phase: study phase; N/A: not applicable.

\begin{tabular}{|c|c|c|c|}
\hline Status/Medical Condition & Listed & Phase & Termination Reason \\
\hline SUSPENDED & 4 & & \\
\hline \multicolumn{4}{|l|}{ Autoimmune Disorders } \\
\hline $\begin{array}{c}\text { Cardiovascular Diseases } \\
\text { Cardiovascular Disease|Renal Insufficiency, Acute|Cardiopulmonary Bypass }\end{array}$ & 1 & 4 & Opposite result \\
\hline \multicolumn{4}{|l|}{ Infectious Diseases } \\
\hline TERMINATED/ & 15 & & \\
\hline $\begin{array}{c}\text { Addiction } \\
\text { Acetaminophen Overdose } \\
\text { Prevention of Hangover Using NAC }\end{array}$ & $\begin{array}{l}1 \\
1\end{array}$ & $\begin{array}{c}3 \\
\mathrm{~N} / \mathrm{A}\end{array}$ & $\begin{array}{l}\text { Insufficient enrollment } \\
\text { Insufficient enrollment }\end{array}$ \\
\hline $\begin{array}{c}\text { Gastrointestinal Diseases } \\
\text { Acute Liver Failure|Fulminant Hepatic Failure } \\
\text { Drug Induced Liver Injury }\end{array}$ & $\begin{array}{l}1 \\
1\end{array}$ & $\begin{array}{c}4 \\
\text { N/A }\end{array}$ & $\begin{array}{l}\text { Insufficient enrollment } \\
2 \text { sepsis cases after } \\
\text { steroid admin. }\end{array}$ \\
\hline \multicolumn{3}{|l|}{ Genetic disorders } & Insufficient enrollment \\
\hline $\begin{array}{l}\text { Infectious Diseases } \\
\text { Helicobacter pylori Infection }\end{array}$ & 1 & $1 \mid 2$ & $\begin{array}{l}\text { Efficacy of eradication: } 2 \\
\text { out of } 31\end{array}$ \\
\hline $\begin{array}{c}\text { Metabolic diseases } \\
\text { Type } 2 \text { Diabetes Mellitus|Hypertension }\end{array}$ & 1 & 4 & N/A \\
\hline \multicolumn{4}{|l|}{ Surgery Complications/Trauma } \\
\hline WITHDRAWN/ & 4 & & \\
\hline $\begin{array}{c}\text { Cancer/Chemotherapy Side Effects } \\
\text { Ovarian Carcinoma, Stage } 3 \text { or } 4 \mid \text { Epithelial Ovarian Carcinoma|Primary Peritoneal Carcinoma }\end{array}$ & 1 & 1 & $\begin{array}{l}\text { No funding for the cost } \\
\text { of NAC }\end{array}$ \\
\hline $\begin{array}{l}\text { Gastrointestinal Diseases } \\
\text { Liver Failure|Liver Failure, Acute|Drug Induced Liver Injury|Prevention and Control|Fever }\end{array}$ & 1 & N/A & Short of funds \\
\hline $\begin{array}{c}\text { Neuro/Psychiatric Disorders } \\
\text { Autistic Disorder|Seizures|Irritability } \\
\text { Posttraumatic Stress Disorder }\end{array}$ & 1 & N/A & $\begin{array}{l}\text { No eligible subjects } \\
\text { located } \\
\text { Cancelled research } \\
\text { project }\end{array}$ \\
\hline Grand Total & 23 & & \\
\hline
\end{tabular}

\section{NAC in Prevention and Complementary Treatment of Cancer}

The role of antioxidants and reactive oxygen species (ROS) in cancer is controversial [86]. Epidemiological studies on synthetic antioxidants supplementation are inconclusive and contradictory mainly due to (1) anti vs. pro-oxidative properties of antioxidant and (2) antioxidant involvement 
in intracellular signaling and redox regulation, which modulate proliferation, apoptosis, and gene expression [87]. This is of particular significance during cell malignant transformation. Antioxidants in general are able to reduce the frequency of the malignant transformation by directly sequestrating ROS or by induction of cellular repair and adaptive stress responses that are important in preventing cancer initiation. For example, in experimental models of breast cancer, N-Acetylcysteine (NAC) reduced cancer aggressiveness, proliferation, and increased apoptosis of cancer cells [88,89]. By decreasing oxidative stress and inflammatory mediators, NAC interferes with intracellular metabolic processes by repressing glycolysis and increasing mitochondrial functioning [90,91]. On the other hand, antioxidant treatment may increase survival of cancer/precancer cells administered after malignant transformation [86]. The antioxidant supplementation in tumor-bearing mice was associated with accelerated cancer progression and increased metastasis in some preclinical studies [92,93]. The combination of N-acetylcysteine (NAC) and soluble vitamin E analog Trolox increased the migration and invasive properties of human malignant melanoma cells in an endogenous mouse model of malignant melanoma [92]. Similarly, N-acetylcysteine and vitamin E accelerated lung cancer progression in mice by reducing survival and increased tumor progression by disrupting the ROS-p53 axis [55].

In patients undergoing cancer therapy, antioxidant supplementation may alleviate unwanted radiation and chemotherapy-induced toxicity by quenching free radicals but also reduce the efficacy of chemo- and radiotherapy. This may increase (malignant and non-malignant) cell survival by altering cellular signal transduction pathways that regulate cell proliferation [94]. The reduction of ROS by antioxidants can lead to the survival of pre-initiated tumor cells, even in unnatural matrix environments [95]. Thus, NAC may have dichotomous effects with respect to tumorigenesis and NAC administration may differ depending on the stage of malignant transformation. By enhancing resistance to oxidative stress and decreased apoptosis during cancer promotion, progression, and treatment stages, NAC supplementation may not always be beneficial, since it may increase cancer cell survival in altered matrix environments by antioxidant restoration of adenosine triphosphate (ATP) generation [96]. Further clinical studies should be performed to address whether NAC administration ameliorates toxic side effects of radiation and chemotherapy with or without affecting the treatment efficacy.

\section{NAC as a Dietary Supplement}

Like many antioxidants, NAC has been very successful in the pharmaceutical, dietary supplement, and nutraceutical markets. In 2016 alone, Europe consumed approximately 3908.2 MT, USA approximately 3005.4 MT, and India approximately 1392.3 MT. The global market for NAC is expected to grow at a compound annual growth rate of about $22 \%$ over the next five years, from 490 million USD in 2017 [97]. Sellers of dietary supplements make a number of claims about the potential of NAC to protect against environmental toxins and pollutants, treat diverse conditions, extend lifespan, and even increase testosterone levels in men-in spite of limited scientific evidence. Little to no reliable information is available about the effects experienced by numerous users of NAC as a dietary supplement. The NAC-containing product with the most reviews on Amazon.com (100\% NAC powder $1 \mathrm{~kg}, 905$ reviews) has an average rating of 4.6 out of 5 stars [98]. Similar ratings can be seen for other popular NAC products. The 95 reviews on the website WebMD [99] convey similar impressions. None of this qualifies as scientific data, but we infer that NAC is popular as a dietary supplement.

\section{NAC as a Sports Supplement, Effects in Skeletal Muscle}

The performance of NAC as a sports supplement is discussed in detail in a recent meta-analysis by Rhodes and Brakhuis [85]. There is a great variability of study results also because of heterogenous methodologies. However, some studies have shown very significant athletic performance increases during repeated bouts of intermittent exercise (up to 50\%) with NAC supplementation, particularly in athletes who have the capacity to generate more ROS in their muscles during exercise [100]. It also appears that the benefits of NAC are more significant when muscles are in a pre-fatigued state, and thus the produced ROS can exceed the buffering capacity of the endogenous antioxidant system. One of the 
major challenges of using NAC as a sports supplement is in the dosage and timing of administration, which are not standardized. For example, the daily dose of NAC in the studies included by Rhodes and Brakhuis varied from 1.2 to $20 \mathrm{~g}$, and the supplementation period from 8 days to minutes before the performance. The heterogenous effects of NAC in various studies reflect the fact that there is a multifactorial optimum to the redox state of various tissues that is challenging to tackle, and either too much or too little of an antioxidant can lead to performance decrease and damage. According to the Rhodes and Brakhuis meta-analysis, larger doses of NAC ( $>5 \mathrm{~g})$ have an increased potential to cause side effects. Even though these side effects are generally mild and limited to gastrointestinal disturbances, they can hamper athletic performance and thus defy the purpose of supplementation. However, the evidence for these side effects is limited, and in several of the studies included in Rhodes and Brakhuis meta-analysis no side effects were reported in spite of the large doses.

\section{NAC as an Anti-Aging Supplement, Effects on Degenerative Processes}

NAC can potentially be effective in degenerative processes caused by aging, for instance, in neurodegenerative disorders, neuropathic pain, and stroke [101]. The present findings from animal studies support a neuroprotective role of NAC in controlling age-related neurological disorders [102]. For instance, NAC protects against Cd-induced neuronal apoptosis in mouse brain partially by inhibiting ROS-dependent activation of Akt/mTOR pathway. The findings highlight that NAC may be exploited for prevention and treatment of Cd-induced neurodegenerative diseases [103]. Animal model results support the possibility that NAC could be explored in clinical trials for amyotrophic lateral sclerosis disease [104], as well as Alzheimer's disease [105] and mild cognitive impairment [106]. Further animal studies have shown that it delays age-associated memory impairment [74] and improves aging-related myocardial dysfunctions [70]. Since oxidative stress plays a prominent role in the modulation of neuropathic pain, NAC could be a potential candidate for its alleviation [107]. Furthermore, NAC could be used in endotoxemic states to prevent oxidative damage [108]. This warrants some caution, because NAC was associated with cardiac performance depression in a human trial [109]. NAC has a potential to improve immune function among the elderly [110]. A recent meta-analysis has also revealed a positive effect of NAC on human cognition, in healthy as well as mentally ill individuals [111]. NAC may be helpful in chronic fatigue syndrome [112]. Topical NAC may prevent UV-associated photoaging of the skin [7]. The synthesis of GSH is decreased in the elderly, which increases oxidative stress, itself a propagator of aging. This effect can be reversed with dietary supplementation [23]. Many medical conditions with beneficial role of NAC that are listed above are aging-associated. Based on these facts and the known molecular mechanisms of NAC as an antioxidant, we can hypothesize that it has potential as an anti-aging supplement. The dosage and timing of administration are even more of a concern here than in the case of sports supplementation, since ameliorating the effects of aging would require its long-term use. This would also raise the question of potential long-term side effects, which remains to be answered.

\section{Summary and Conclusion, Future Perspectives}

NAC is an established generic mucolytic and paracetamol poisoning antidote, but the list of conditions it can potentially improve has grown steadily over the years, and so has its popularity as a dietary supplement. In in vitro as well as in animal experiments it has exhibited potent antioxidant properties, which make NAC a powerful tool for diseases and states where ROS are the major cause of damage. However, modulating the redox state of cells, tissues, and organs is a delicate matter, and turning the dial too far in the antioxidant direction can cause more harm than good. Combined with heterogenous methodologies and a lack of standardization, the results of different studies are bound to conflict, which complicates the deduction of NAC's effects. This is the major setback, since without determining the necessity, dosage, and timing of administration, optimal balancing of the redox scales is not possible. Developing and implementing technologies to measure the personalized levels of ROS and other oxidants and adjust the doses of antioxidants accordingly instead of using 
them blindly would provide an advantage, but also clinical and technological challenges. There is a wealth of unexploited information in the form of thousands of anonymous users of NAC as a dietary supplement. Since there is no regulation or documentation of this usage, we are missing out on potential information about the effects of NAC (and other antioxidants) in large numbers of people. Even though (especially oral) administration of NAC has been safe, the results of clinical trials for many conditions are still indecisive. Like other supplemented antioxidants, it may be harmful in the case of cancer or premalignancy, but there seem no other obstacles to studying NAC in many other conditions. More clinical trials of its use in neurodegenerative diseases, addiction, and mental health disorders are underway. This will provide much-needed information on NAC, and may be relevant to the supplement users. At the same time, it may help people suffering from chronic degenerative conditions.

Author Contributions: S.S. and B.P. wrote a manuscript draft, I.M. conceived and finalized the manuscript with inputs from all authors. B.K., T.P.M., and I.M. analyzed Clinical Trials data and produced all tables.

Funding: B.P. and I.M. are partially supported by Slovenian Research Agency (research core funding No. P3-0388 and P3-0019, respectively). B.K. is supported by the H2020-MSCA-ITN:721236 TREATMENT project and T.P.M. by the Slovenian Research Agency Early Stage Researcher Scheme.

Conflicts of Interest: The authors declare no conflict of interest.

\section{References}

1. Pieralisi, A.; Martini, C.; Soto, D.; Vila, M.C.; Calvo, J.C.; Guerra, L.N. N-acetylcysteine inhibits lipid accumulation in mouse embryonic adipocytes. Redox Biol. 2016, 9, 39-44. [CrossRef]

2. Diniz, Y.S.; Rocha, K.K.H.R.; Souza, G.A.; Galhardi, C.M.; Ebaid, G.M.X.; Rodrigues, H.G.; Novelli Filho, J.L.V.B.; Cicogna, A.C.; Novelli, E.L.B. Effects of N-acetylcysteine on sucrose-rich diet-induced hyperglycaemia, dyslipidemia and oxidative stress in rats. Eur. J. Pharmacol. 2006, 543, 151-157. [CrossRef]

3. Campos, K.E.; Diniz, Y.S.; Cataneo, A.C.; Faine, L.A.; Alves, M.J.Q.F.; Novelli, E.L.B. Hypoglycaemic and antioxidant effects of onion, Allium cepa: Dietary onion addition, antioxidant activity and hypoglycaemic effects on diabetic rats. Int. J. Food Sci. Nutr. 2003, 54, 241-246. [CrossRef]

4. Radomska-Leśniewska, D.M.; Skopiński, P. N-acetylcysteine as an anti-oxidant and anti-inflammatory drug and its some clinical applications. Cent. J. Immunol. 2012, 37, 57-66.

5. Bavarsad Shahripour, R.; Harrigan, M.R.; Alexandrov, A.V. N-acetylcysteine (NAC) in neurological disorders: mechanisms of action and therapeutic opportunities. Brain Behav. 2014, 4, 108-122. [CrossRef]

6. Guo, F.; Li, Y.; Wang, J.; Li, Y.; Li, Y.; Li, G. Stanniocalcin1 (STC1) Inhibits Cell Proliferation and Invasion of Cervical Cancer Cells. PLoS One 2013, 8, e53989. [CrossRef]

7. Kang, S.; Chung, J.H.; Lee, J.H.; Fisher, G.J.; Wan, Y.S.; Duell, E.A.; Voorhees, J.J. Topical N-Acetyl Cysteine and Genistein Prevent Ultraviolet-Light-Induced Signaling That Leads to Photoaging in Human Skin in vivo. J. Invest. Dermatol. 2003, 120, 835-841. [CrossRef]

8. Schmitt, B.; Vicenzi, M.; Garrel, C.; Denis, F.M. Effects of N-acetylcysteine, oral glutathione (GSH) and a novel sublingual form of GSH on oxidative stress markers: A comparative crossover study. Redox Biol. 2015, 6, 198-205. [CrossRef]

9. Mokhtari, V.; Afsharian, P.; Shahhoseini, M.; Kalantar, S.M.; Moini, A. A Review on Various Uses of N-Acetyl Cysteine. Cell J. 2017, 19, 11-17.

10. Dludla, P.V.; Nkambule, B.B.; Dias, S.C.; Johnson, R. Cardioprotective potential of N-acetyl cysteine against hyperglycaemia-induced oxidative damage: a protocol for a systematic review. Syst. Rev. 2017, 6, 96. [CrossRef]

11. de Andrade, K.; Moura, F.; dos Santos, J.; de Araújo, O.; de Farias Santos, J.; Goulart, M.; De Andrade, K.Q.; Moura, F.A.; Dos Santos, J.M.; De Araújo, O.R.P.; et al. Oxidative Stress and Inflammation in Hepatic Diseases: Therapeutic Possibilities of N-Acetylcysteine. Int. J. Mol. Sci. 2015, 16, 30269-30308. [CrossRef]

12. Hoffer, B.J.; Pick, C.G.; Hoffer, M.E.; Becker, R.E.; Chiang, Y.-H.; Greig, N.H. Repositioning drugs for traumatic brain injury - N-acetyl cysteine and Phenserine. J. Biomed. Sci. 2017, 24, 71. [CrossRef]

13. Smith, L.; Tracy, D.K.; Giaroli, G. What Future Role Might N-Acetyl-Cysteine Have in the Treatment of Obsessive Compulsive and Grooming Disorders? J. Clin. Psychopharmacol. 2016, 36, 57-62. [CrossRef]

14. Plemenitaš, A. Prehrana in prehranska dopolnila v psihiatriji. Slov. Med. J. 2018, 87, 1-2. [CrossRef] 
15. di Michele, F.; Siracusano, A.; Talamo, A.; Niolu, C. N-Acetyl Cysteine and Vitamin D Supplementation in Treatment Resistant Obsessive-compulsive Disorder Patients: A General Review. Curr. Pharm. Des. 2018, 24, 1832-1838. [CrossRef]

16. Schafer, F.Q.; Buettner, G.R. Redox environment of the cell as viewed through the redox state of the glutathione disulfide/glutathione couple. Free Radic. Biol. Med. 2001, 30, 1191-1212. [CrossRef]

17. Jeong, E.M.; Yoon, J.-H.; Lim, J.; Shin, J.-W.; Cho, A.Y.; Heo, J.; Lee, K.B.; Lee, J.-H.; Lee, W.J.; Kim, H.-J.; et al. Real-Time Monitoring of Glutathione in Living Cells Reveals that High Glutathione Levels Are Required to Maintain Stem Cell Function. Stem Cell Rep. 2018. [CrossRef]

18. Franco, R.; Cidlowski, J.A. Glutathione efflux and cell death. Antioxid. Redox Signal. 2012, 17, $1694-1713$. [CrossRef]

19. Damy, T.; Kirsch, M.; Khouzami, L.; Caramelle, P.; Le Corvoisier, P.; Roudot-Thoraval, F.; Dubois-Randé, J.-L.; Hittinger, L.; Pavoine, C.; Pecker, F. Glutathione Deficiency in Cardiac Patients is Related to the Functional Status and Structural Cardiac Abnormalities. PLoS One 2009, 4, e4871. [CrossRef]

20. Lutchmansingh, F.K.; Hsu, J.W.; Bennett, F.I.; Badaloo, A.V.; McFarlane-Anderson, N.; Gordon-Strachan, G.M.; Wright-Pascoe, R.A.; Jahoor, F.; Boyne, M.S. Glutathione metabolism in type 2 diabetes and its relationship with microvascular complications and glycemia. PLoS One 2018, 13, e0198626. [CrossRef]

21. Doss, S.; Rinnenthal, J.L.; Schmitz-Hübsch, T.; Brandt, A.U.; Papazoglou, S.; Lux, S.; Maul, S.; Würfel, J.; Endres, M.; Klockgether, T.; et al. Cerebellar neurochemical alterations in spinocerebellar ataxia type 14 appear to include glutathione deficiency. J. Neurol. 2015, 262, 1927-1935. [CrossRef] [PubMed]

22. Dröge, W. Cysteine and Glutathione Deficiency in AIDS Patients: A Rationale for the Treatment with IM-Acetyl-Cysteine. Pharmacol. 1993, 46, 61-65.

23. Sekhar, R.V.; Patel, S.G.; Guthikonda, A.P.; Reid, M.; Balasubramanyam, A.; Taffet, G.E.; Jahoor, F. Deficient synthesis of glutathione underlies oxidative stress in aging and can be corrected by dietary cysteine and glycine supplementation. Am. J. Clin. Nutr. 2011, 94, 847-853. [CrossRef] [PubMed]

24. Halliwell, B.; Gutteridge, J.M.C. Free Radicals in Biology and Medicine, 4th ed.; Oxford University Press: Oxford, UK, 2007.

25. Aruoma, O.I.; Halliwell, B.; Hoey, B.M.; Butler, J. The antioxidant action of N-acetylcysteine: Its reaction with hydrogen peroxide, hydroxyl radical, superoxide, and hypochlorous acid. Free Radic. Biol. Med. 1989, 6, 593-597. [CrossRef]

26. Benrahmoune, M.; Thérond, P.; Abedinzadeh, Z. The reaction of superoxide radical with N-acetylcysteine. Free Radic. Biol. Med. 2000, 29, 775-782. [CrossRef]

27. Moldéus, P.; Cotgreave, I.A.; Berggren, M. Lung Protection by a Thiol-Containing Antioxidant: N-Acetylcysteine. Respiration 1986, 50, 31-42. [CrossRef] [PubMed]

28. Corinne Sprong, R.; Winkelhuyzen-Janssen, A.M.L.; Aarsman, C.J.; van Oirschot, J.F.; van der Bruggen, T.J.O.M.M.E.; Sweder van Asbeck, B. Low-dose N-Acetylcysteine Protects Rats against Endotoxin-mediated Oxidative Stress, But High-dose Increases Mortality. Am. J. Respir. Crit. Care Med. 1998, 157, 1283-1293. [CrossRef]

29. Spear, N.; Aust, S.D. Hydroxylation of Deoxyguanosine in DNA by Copper and Thiols. Arch. Biochem. Biophys. 1995, 317, 142-148. [CrossRef] [PubMed]

30. Das, K.C.; Lewis-Molock, Y.; White, C.W. Activation of NF-kappa B and elevation of MnSOD gene expression by thiol reducing agents in lung adenocarcinoma (A549) cells. Am. J. Physiol. Cell. Mol. Physiol. 1995, 269, L588-L602. [CrossRef] [PubMed]

31. Chan, E.D.; Riches, D.W.H.; White, C.W. Redox Paradox: Effect of N-Acetylcysteine and Serum on Oxidation Reduction-Sensitive Mitogen-Activated Protein Kinase Signaling Pathways. Am. J. Respir. Cell Mol. Biol. 2001, 24, 627-632. [CrossRef]

32. Sagristá, M.L.; García, A.E.; Africa De Madariaga, M.; Mora, M. Antioxidant and pro-oxidant effect of the thiolic compounds N-acetyl-L-cysteine and glutathione against free radical-induced lipid peroxidation. Free Radic. Res. 2002, 36, 329-340. [CrossRef] [PubMed]

33. World Health Organization. WHO Model List of Essential Medicines: 20th List. March 2017. Available online: http://www.who.int/medicines/publications/essentialmedicines/20th_EML2017_FINAL_ amendedAug2017.pdf?ua=1 (accessed on 27 March 2019).

34. FDA. Acetadote (acetylcysteine) Injection Package Insert. Available online: https://www.accessdata.fda.gov/ drugsatfda_docs/nda/2004/21-539_Acetadote.cfm (accessed on 27 March 2019). 
35. Slattery, J.; Kumar, N.; Delhey, L.; Berk, M.; Dean, O.; Spielholz, C.; Frye, R. Clinical trials of N-acetylcysteine in psychiatry and neurology: A systematic review. Neurosci. Biobehav. Rev. 2015, 55, 294-321.

36. Pannu, N.; Manns, B.; Lee, H.; Tonelli, M. Systematic review of the impact of N-acetylcysteine on contrast nephropathy. Kidney Int. 2004, 65, 1366-1374. [CrossRef] [PubMed]

37. Center for Drug Evaluation and Research. Application no. 21-539. Medical Review (Robert Prizont, MD), 2003. Available online: https://www.accessdata.fda.gov/drugsatfda_docs/nda/2004/21-539_Acetadote_Medr.pdf (accessed on 13 February 2019).

38. Mroz, L.S.; Benitez, J.G.; Krenzelok, E.P. Angioedema with oral N-acetylcysteine. Ann. Emerg. Med. 1997, 30, 240-241. [PubMed]

39. De Oliveira, C.P.; Stefano, J.T.; De Siqueira, E.R.; Silva, L.S.; De Campos Mazo, D.F.; Lima, V.M.; Furuya, C.K.; Mello, E.S.; Souza, F.G.; Rabello, F.; et al. Combination of N-acetylcysteine and metformin improves histological steatosis and fibrosis in patients with non-alcoholic steatohepatitis. Hepatol. Res. 2008, 38, 159-165. [CrossRef]

40. Martina, V.; Masha, A.; Gigliardi, V.R.; Brocato, L.; Manzato, E.; Berchio, A.; Massarenti, P.; Settanni, F.; Della Casa, L.; Bergamini, S.; et al. Long Term N-Acetylcysteine and L-Arginine Administration Reduces Endothelial Activation and Systolic Blood Pressure in Hypertensive Patients with Type 2 Diabetes Mellitus. Diabetes Care 2008, 31, 940-944. [CrossRef] [PubMed]

41. Tse, H.N.; Tseng, C.Z.S. Update on the pathological processes, molecular biology, and clinical utility of $\mathrm{N}$-acetylcysteine in chronic obstructive pulmonary disease. Int. J. Chron. Obstruct. Pulmon. Dis. 2014, 9, 825-836. [CrossRef]

42. Pirabbasi, E.; Shahar, S.; Manaf, Z.A.; Rajab, N.F.; Manap, R.A. Efficacy of Ascorbic Acid (Vitamin C) and/N-Acetylcysteine (NAC) Supplementation on Nutritional and Antioxidant Status of Male Chronic Obstructive Pulmonary Disease (COPD) Patients. J. Nutr. Sci. Vitaminol. (Tokyo) 2016, 62, 54-61. [CrossRef]

43. Stey, C.; Steurer, J.; Bachmann, S.; Medici, T.C.; Tramèr, M.R. The effect of oral N-acetylcysteine in chronic bronchitis: a quantitative systematic review. Eur. Respir. J. 2000, 16, 253-262. [CrossRef]

44. McClure, E.A.; Gipson, C.D.; Malcolm, R.J.; Kalivas, P.W.; Gray, K.M. Potential role of N-acetylcysteine in the management of substance use disorders. CNS Drugs 2014, 28, 95-106. [CrossRef]

45. Amin, A.F.; Shaaban, O.M.; Bediawy, M.A. N-acetyl cysteine for treatment of recurrent unexplained pregnancy loss. Reprod. Biomed. Online 2008, 17, 722-726. [CrossRef]

46. Safarinejad, M.R.; Safarinejad, S. Efficacy of Selenium and/or N-Acetyl-Cysteine for Improving Semen Parameters in Infertile Men: A Double-Blind, Placebo Controlled, Randomized Study. J. Urol. 2009, 181, 741-751. [CrossRef] [PubMed]

47. Fulghesu, A.M.; Ciampelli, M.; Muzj, G.; Belosi, C.; Selvaggi, L.; Ayala, G.F.; Lanzone, A. N-acetyl-cysteine treatment improves insulin sensitivity in women with polycystic ovary syndrome. Fertil. Steril. 2002, 77, 1128-1135. [CrossRef]

48. ClinicalTrials.gov. Available online: https://clinicaltrials.gov (accessed on 2 April 2019).

49. Chen, A.T.; Chibnall, J.T.; Nasrallah, H.A. Placebo-controlled augmentation trials of the antioxidant NAC in schizophrenia: A review. Ann. Clin. Psychiatry 2016, 28, 190-196. [PubMed]

50. Rapado-Castro, M.; Dodd, S.; Bush, A.I.; Malhi, G.S.; Skvarc, D.R.; On, Z.X.; Berk, M.; Dean, O.M. Cognitive effects of adjunctive N-acetyl cysteine in psychosis. Psychol. Med. 2017, 47, 866-876. [CrossRef] [PubMed]

51. Hopf, F.W. Do specific NMDA receptor subunits act as gateways for addictive behaviors? Genes. Brain. Behav. 2017, 16, 118-138. [CrossRef] [PubMed]

52. Tomko, R.L.; Jones, J.L.; Gilmore, A.K.; Brady, K.T.; Back, S.E.; Gray, K.M. N-acetylcysteine: A potential treatment for substance use disorders. Curr. Psychiatr. 2018, 17, 30-36, 41-42, 55. [PubMed]

53. Nocito Echevarria, M.A.; Andrade Reis, T.; Ruffo Capatti, G.; Siciliano Soares, V.; da Silveira, D.X.; Fidalgo, T.M. $\mathrm{N}$-acetylcysteine for treating cocaine addiction - A systematic review. Psychiatry Res. 2017, 251, 197-203. [CrossRef]

54. Johnson, K.; McEvoy, C.E.; Naqvi, S.; Wendt, C.; Reilkoff, R.A.; Kunisaki, K.M.; Wetherbee, E.E.; Nelson, D.; Tirouvanziam, R.; Niewoehner, D.E. High-dose oral N-acetylcysteine fails to improve respiratory health status in patients with chronic obstructive pulmonary disease and chronic bronchitis: A randomized, placebo-controlled trial. Int. J. Chron. Obstruct. Pulmon. Dis. 2016, 11, 799-807.

55. Sayin, V.I.; Ibrahim, M.X.; Larsson, E.; Nilsson, J.A.; Lindahl, P.; Bergo, M.O. Antioxidants Accelerate Lung Cancer Progression in Mice. Sci. Transl. Med. 2014, 6, 221ra15. [CrossRef] 
56. Conrad, C.; Lymp, J.; Thompson, V.; Dunn, C.; Davies, Z.; Chatfield, B.; Nichols, D.; Clancy, J.; Vender, R.; Egan, M.E.; et al. Long-term treatment with oral N-acetylcysteine: Affects lung function but not sputum inflammation in cystic fibrosis subjects. A phase II randomized placebo-controlled trial. J. Cyst. Fibros. 2015, 14, 219-227. [CrossRef]

57. Weisbord, S.D.; Gallagher, M.; Jneid, H.; Garcia, S.; Cass, A.; Thwin, S.-S.; Conner, T.A.; Chertow, G.M.; Bhatt, D.L.; Shunk, K.; et al. Outcomes after Angiography with Sodium Bicarbonate and Acetylcysteine. N. Engl. J. Med. 2018, 378, 603-614. [CrossRef]

58. ACT Investigators. Acetylcysteine for Prevention of Renal Outcomes in Patients Undergoing Coronary and Peripheral Vascular Angiography. Circulation 2011, 124, 1250-1259. [CrossRef] [PubMed]

59. Moreira, P.I.; Harris, P.L.R.; Zhu, X.; Santos, M.S.; Oliveira, C.R.; Smith, M.A.; Perry, G. Lipoic acid and $\mathrm{N}$-acetyl cysteine decrease mitochondrial-related oxidative stress in Alzheimer disease patient fibroblasts. J. Alzheimers. Dis. 2007, 12, 195-206. [CrossRef] [PubMed]

60. Parachikova, A.; Green, K.N.; Hendrix, C.; Laferla, F.M. Formulation of a medical food cocktail for Alzheimer's disease: Beneficial effects on cognition and neuropathology in a mouse model of the disease. PLoS One 2010, 5, e14015. [CrossRef] [PubMed]

61. Blesa, S.; Cortijo, J.; Martinez-losa, M.; Mata, M.; Seda, E.; Santangelo, F.; Morcillo, E.J. Effectiveness of oral $\mathrm{N}$-acetylcysteine in a rat experimental model of asthma. Pharmacol. Res. 2002, 45, 135-140. [CrossRef] [PubMed]

62. Wang, Q.; Hou, Y.; Yi, D.; Wang, L.; Ding, B.; Chen, X.; Long, M.; Liu, Y.; Wu, G. Protective effects of $\mathrm{N}$-acetylcysteine on acetic acid-induced colitis in a porcine model. BMC Gastroenterol. 2013, 13, 133. [CrossRef] [PubMed]

63. Anfossi, G.; Russo, I.; Massucco, P.; Mattiello, L.; Cavalot, F.; Trovati, M. N-acetyl-L-cysteine exerts direct anti-aggregating effect on human platelets. Eur. J. Clin. Invest. 2001, 31, 452-461. [CrossRef]

64. Zhang, H.; Li, Y.; Chen, Y.; Zhang, L.; Wang, T. N-Acetylcysteine protects against intrauterine growth retardation-induced intestinal injury via restoring redox status and mitochondrial function in neonatal piglets. Eur. J. Nutr. 2018, 1-13. [CrossRef]

65. Calzadilla, P.; Gómez-Serrano, M.; García-Santos, E.; Schiappacasse, A.; Abalde, Y.; Calvo, J.C.; Peral, B.; Guerra, L.N. N -Acetylcysteine affects obesity-related protein expression in 3T3-L1 adipocytes. Redox Rep. 2013, 18, 210-218. [CrossRef]

66. Kim, J.-R.; Ryu, H.-H.; Chung, H.J.; Lee, J.H.; Kim, S.W.; Kwun, W.H.; Baek, S.-H.; Kim, J.H. Association of anti-obesity activity of $\mathrm{N}$-acetylcysteine with metallothionein-II down-regulation. Exp. Mol. Med. 2006, 38, 162-172. [CrossRef]

67. Novelli, E.L.B.; Santos, P.P.; Assalin, H.B.; Souza, G.; Rocha, K.; Ebaid, G.X.; Seiva, F.R.F.; Mani, F.; Fernandes, A.A. N-acetylcysteine in high-sucrose diet-induced obesity: Energy expenditure and metabolic shifting for cardiac health. Pharmacol. Res. 2009, 59, 74-79. [CrossRef]

68. Shen, F.-C.; Weng, S.-W.; Tsao, C.-F.; Lin, H.-Y.; Chang, C.-S.; Lin, C.-Y.; Lian, W.-S.; Chuang, J.-H.; Lin, T.-K.; Liou, C.-W.; et al. Early intervention of $\mathrm{N}$-acetylcysteine better improves insulin resistance in diet-induced obesity mice. Free Radic. Res. 2018, 52, 1-11. [CrossRef]

69. Zhu, Z.; Takahashi, N.; Ooie, T.; Shinohara, T.; Yamanaka, K.; Saikawa, T. Oral Administration of Geranylgeranylacetone Blunts the Endothelial Dysfunction Induced by Ischemia and Reperfusion in the Rat Heart. J. Cardiovasc. Pharmacol. 2005, 45, 555-562. [CrossRef]

70. Hemmeryckx, B.; Hohensinner, P.; Swinnen, M.; Heggermont, W.; Wojta, J.; Lijnen, H.R. Antioxidant Treatment Improves Cardiac Dysfunction in a Murine Model of Premature Aging. J. Cardiovasc. Pharmacol. 2016, 68, 374-382. [CrossRef]

71. Zhang, D.; Li, Y.; Zhang, T.; Liu, J.; Jahejo, A.R.; Yang, L.; Chen, P.; Ning, G.; Huo, N.; Ma, H.; et al. Protective effects of zinc and N-acetyl-L-cysteine supplementation against cadmium induced erythrocyte cytotoxicity in Arbor Acres broiler chickens (Gallus gallus domesticus). Ecotoxicol. Environ. Saf. 2018, 163, 331-339. [CrossRef]

72. Flora, S.J.S. Structural, chemical and biological aspects of antioxidants for strategies against metal and metalloid exposure. Oxid. Med. Cell. Longev. 2009, 2, 191-206. [CrossRef]

73. Sagara, M.; Satoh, J.; Wada, R.; Yagihashi, S.; Takahashi, K.; Fukuzawa, M.; Muto, G.; Muto, Y.; Toyota, T. Inhibition of development of peripheral neuropathy in streptozotocin-induced diabetic rats with N-acetylcysteine. Diabetologia 1996, 39, 263-269. [CrossRef] 
74. Martínez, M.; Hernández, A.I.; Martínez, N. N-Acetylcysteine delays age-associated memory impairment in mice: role in synaptic mitochondria. Brain Res. 2000, 855, 100-106. [CrossRef]

75. Dinicola, S.; De Grazia, S.; Carlomagno, G.; Pintucci, J.P. N-acetylcysteine as powerful molecule to destroy bacterial biofilms. A systematic review. Eur. Rev. Med. Pharmacol. Sci. 2014, 18, 2942-2948.

76. Brack, C.; Bechter-Thüring, E.; Labuhn, M. N-Acetylcysteine slows down ageing and increases the life span of Drosophila melanogaster. Cell. Mol. Life Sci. 1997, 53, 960-966. [CrossRef]

77. Oh, S.; Park, J.; Park, S. Lifespan extension and increased resistance to environmental stressors by N-Acetyl-L-Cysteine in Caenorhabditis elegans. Clinics 2015, 70, 380-386. [CrossRef]

78. Shaposhnikov, M.V.; Zemskaya, N.V.; Koval, L.A.; Schegoleva, E.V.; Zhavoronkov, A.; Moskalev, A.A. Effects of N-acetyl-L-cysteine on lifespan, locomotor activity and stress-resistance of 3 Drosophila species with different lifespans. Aging (Albany NY) 2018, 10, 2428-2458. [CrossRef] [PubMed]

79. Oh, S.-I.; Park, S.-K. N-acetyl-1-cysteine mimics the effect of dietary restriction on lifespan and reduces amyloid beta-induced toxicity in Caenorhabditis elegans. Food Sci. Biotechnol. 2017, 26, 783-790. [CrossRef] [PubMed]

80. Flurkey, K.; Astle, C.M.; Harrison, D.E. Life Extension by Diet Restriction and N-Acetyl-L-Cysteine in Genetically Heterogeneous Mice. J. Gerontol. Ser. A Biol. Sci. Med. Sci. 2010, 65A, 1275-1284. [CrossRef]

81. Wang, K.-H.; Kao, A.-P.; Chang, C.-C.; Lin, T.-C.; Kuo, T.-C. Lifespan Extension and Sustained Expression of Stem Cell Phenotype of Human Breast Epithelial Stem Cells in a Medium with Antioxidants. Stem Cells Int. 2016, 2016, 1-9. [CrossRef]

82. Shi, T.; Yang, X.; Zhou, H.; Xi, J.; Sun, J.; Ke, Y.; Zhang, J.; Shao, Y.; Jiang, X.; Pan, X.; et al. Activated carbon $\mathrm{N}$-acetylcysteine microcapsule protects against nonalcoholic fatty liver disease in young rats via activating telomerase and inhibiting apoptosis. PLoS One 2018, 13, e0189856. [CrossRef]

83. Liu, J.; Liu, M.; Ye, X.; Liu, K.; Huang, J.; Wang, L.; Ji, G.; Liu, N.; Tang, X.; Baltz, J.M.; et al. Delay in oocyte aging in mice by the antioxidant N-acetyl-1-cysteine (NAC). Hum. Reprod. 2012, 27, 1411-1420. [CrossRef] [PubMed]

84. Desjardins, D.; Cacho-Valadez, B.; Liu, J.-L.; Wang, Y.; Yee, C.; Bernard, K.; Khaki, A.; Breton, L.; Hekimi, S. Antioxidants reveal an inverted U-shaped dose-response relationship between reactive oxygen species levels and the rate of aging in Caenorhabditis elegans. Aging Cell 2017, 16, 104-112. [CrossRef]

85. Rhodes, K.; Braakhuis, A. Performance and Side Effects of Supplementation with N-Acetylcysteine: A Systematic Review and Meta-Analysis. Sport. Med. 2017, 47, 1619-1636. [CrossRef]

86. Poljsak, B.; Milisav, I. The role of antioxidants in cancer, friends or foes? Curr. Pharm. Des. 2018, 24, 5234-5244. [CrossRef] [PubMed]

87. Poljsak, B. Strategies for Reducing or Preventing the Generation of Oxidative Stress. Oxid. Med. Cell. Longev. 2011, 2011, 1-15. [CrossRef]

88. Martinez-Outschoorn, U.E.; Peiris-Pagés, M.; Pestell, R.G.; Sotgia, F.; Lisanti, M.P. Cancer metabolism: a therapeutic perspective. Nat. Rev. Clin. Oncol. 2017, 14, 11-31. [CrossRef]

89. Agarwal, A.; Muñoz-Nájar, U.; Klueh, U.; Shih, S.-C.; Claffey, K.P. N-acetyl-cysteine promotes angiostatin production and vascular collapse in an orthotopic model of breast cancer. Am. J. Pathol. 2004, 164, 1683-1696. [CrossRef]

90. Elbini Dhouib, I.; Jallouli, M.; Annabi, A.; Gharbi, N.; Elfazaa, S.; Lasram, M.M. A minireview on N -acetylcysteine: An old drug with new approaches. Life Sci. 2016, 151, 359-363. [CrossRef]

91. Balansky, R.; Izzotti, A.; Scatolini, L.; D'Agostini, F.; De Flora, S. Induction by carcinogens and chemoprevention by N-acetylcysteine of adducts to mitochondrial DNA in rat organs. Cancer Res. 1996, 56, 1642-1647.

92. Le Gal, K.; Ibrahim, M.X.; Wiel, C.; Sayin, V.I.; Akula, M.K.; Karlsson, C.; Dalin, M.G.; Akyürek, L.M.; Lindahl, P.; Nilsson, J.; et al. Antioxidants can increase melanoma metastasis in mice. Sci. Transl. Med. 2015, 7, 308re8. [CrossRef]

93. Piskounova, E.; Agathocleous, M.; Murphy, M.M.; Hu, Z.; Huddlestun, S.E.; Zhao, Z.; Leitch, A.M.; Johnson, T.M.; DeBerardinis, R.J.; Morrison, S.J. Oxidative stress inhibits distant metastasis by human melanoma cells. Nature 2015, 527, 186-191. [CrossRef] [PubMed]

94. Zhou, M.; Gu, L.; Zhu, N.; Woods, W.G.; Findley, H.W. Transfection of a dominant-negative mutant NF-kB inhibitor $(\mathrm{IkBm})$ represses p53-dependent apoptosis in acute lymphoblastic leukemia cells: Interaction of IkBm and p53. Oncogene 2003, 22, 8137-8144. [CrossRef] [PubMed] 
95. Schafer, Z.T.; Grassian, A.R.; Song, L.; Jiang, Z.; Gerhart-Hines, Z.; Irie, H.Y.; Gao, S.; Puigserver, P.; Brugge, J.S. Antioxidant and oncogene rescue of metabolic defects caused by loss of matrix attachment. Nature 2009, 461, 109-113. [CrossRef] [PubMed]

96. Watson, J. Oxidants, antioxidants and the current incurability of metastatic cancers. Open Biol. 2013, 3, 120144. [CrossRef] [PubMed]

97. SBWIRE. Global Acetylcysteine Market Size will Grow from US\$490 Million to US\$1650 Million by 2024. Available online: http://www.sbwire.com/press-releases/global-acetylcysteine-market-revenue-will-growat-223-cagr-to-2024-with-us-1650-million-market-size-1142001.htm (accessed on 24 February 2019).

98. Amazon.com, NAC powder. Available online: https://www.amazon.com/dp/B00F8HGA0E?aaxitk= XgCsjwjJY0uReP.ey4bLiQ\&pd_rd_i=B00F8HGA0E\&pf_rd_p=3fade48a-e699-4c96-bf08-bb772ac0e242\& hsa_cr_id=4339168660001\&sb-ci-n=productDescription\&sb-ci-v=BulkSupplements\%2BNAC\%2B(NAcetyl\%2BL-Cysteine)\%2BPowder\%2B(250\%2Bgrams)\&th=1 (accessed on 27 February 2019).

99. WebMD. Available online: https://www.webmd.com/vitamins-supplements/ingredientreview-1018-NACETYL+CYSTEINE.aspx?drugid=1018\&drugname=N-ACETYL+CYSTEINE\&sortby=3 (accessed on 12 February 2019).

100. Cobley, J.N.; McGlory, C.; Morton, J.P.; Close, G.L. N-Acetylcysteine's attenuation of fatigue after repeated bouts of intermittent exercise: Practical implications for tournament situations. Int. J. Sport Nutr. Exerc. Metab. 2011, 21, 451-461. [CrossRef]

101. Tardiolo, G.; Bramanti, P.; Mazzon, E. Overview on the Effects of N-Acetylcysteine in Neurodegenerative Diseases. Molecules 2018, 23, 3305. [CrossRef]

102. Garg, G.; Singh, S.; Singh, A.K.; Rizvi, S.I. N-acetyl-L-cysteine attenuates oxidative damage and neurodegeneration in rat brain during aging. Can. J. Physiol. Pharmacol. 2018, 96, 1189-1196. [CrossRef]

103. Chen, S.; Ren, Q.; Zhang, J.; Ye, Y.; Zhang, Z.; Xu, Y.; Guo, M.; Ji, H.; Xu, C.; Gu, C.; et al. N-acetyl-L-cysteine protects against cadmium-induced neuronal apoptosis by inhibiting ROS-dependent activation of Akt/mTOR pathway in mouse brain. Neuropathol. Appl. Neurobiol. 2014, 40, 759-777. [CrossRef] [PubMed]

104. Andreassen, O.A.; Dedeoglu, A.; Klivenyi, P.; Beal, M.F.; Bush, A.I. N-acetyl-L-cysteine improves survival and preserves motor performance in an animal model of familial amyotrophic lateral sclerosis. Neuroreport 2000, 11, 2491-2493. [CrossRef]

105. Pocernich, C.B.; Lange, M.L.B.; Sultana, R.; Butterfield, D.A. Nutritional approaches to modulate oxidative stress in Alzheimer's disease. Curr. Alzheimer Res. 2011, 8, 452-469. [CrossRef]

106. Huang, Q.; Aluise, C.D.; Joshi, G.; Sultana, R.; St. Clair, D.K.; Markesbery, W.R.; Butterfield, D.A. Potential in vivo amelioration by $\mathrm{N}$-acetyl-L-cysteine of oxidative stress in brain in human double mutant APP/PS-1 knock-in mice: Toward therapeutic modulation of mild cognitive impairment. J. Neurosci. Res. 2010, 88, 2618-2629.

107. Naik, A.K.; Tandan, S.K.; Dudhgaonkar, S.P.; Jadhav, S.H.; Kataria, M.; Prakash, V.R.; Kumar, D. Role of oxidative stress in pathophysiology of peripheral neuropathy and modulation by N-acetyl-L-cysteine in rats. Eur. J. Pain 2006, 10, 573. [CrossRef] [PubMed]

108. Zhang, H.; Spapen, H.; Nguyen, D.N.; Rogiers, P.; Bakker, J.; Vincent, J.L. Effects of N-Acetyl-L-Cysteine on Regional Blood Flow during Endotoxic Shock. Eur. Surg. Res. 1995, 27, 292-300. [CrossRef] [PubMed]

109. Peake, S.L.; Moran, J.L.; Leppard, P.I. N-acetyl-L-cysteine depresses cardiac performance in patients with septic shock. Crit. Care Med. 1996, 24, 1302-1310. [CrossRef]

110. Arranz, L.; Fernández, C.; Rodríguez, A.; Ribera, J.M.; De la Fuente, M. The glutathione precursor $\mathrm{N}$-acetylcysteine improves immune function in postmenopausal women. Free Radic. Biol. Med. 2008, 45, 1252-1262. [CrossRef] [PubMed]

111. Skvarc, D.R.; Dean, O.M.; Byrne, L.K.; Gray, L.; Lane, S.; Lewis, M.; Fernandes, B.S.; Berk, M.; Marriott, A. The effect of N-acetylcysteine (NAC) on human cognition - A systematic review. Neurosci. Biobehav. Rev. 2017, 78, 44-56. [CrossRef] [PubMed]

112. Logan, A.C.; Wong, C. Chronic fatigue syndrome: Oxidative stress and dietary modifications. Altern. Med. Rev. 2001, 6, 450-460. [PubMed]

(C) 2019 by the authors. Licensee MDPI, Basel, Switzerland. This article is an open access article distributed under the terms and conditions of the Creative Commons Attribution (CC BY) license (http://creativecommons.org/licenses/by/4.0/). 